\title{
PELATIHAN PERSIAPAN KEGIATAN OLIMPIADE MATEMATIKA SEBAGAI TAMBAHAN EKSTRAKURIKULER DI SMAN 2 TANJUNG BALAI TAHUN PELAJARAN 2017/2018.
}

\author{
Anim $^{* 1}$, Elfira Rahmadani ${ }^{1}$, Yogo Dwi Prasetyo ${ }^{1}$ \\ Program Studi Pendidikan Matematika, FKIP Universitas Asahan \\ Email:*animfaqot30031991@ gmail.com
}

\begin{abstract}
Many ways taken by the government to realize the human resources of Indonesia with intellectual ability that can compete with the region even with other countries, one of them with a Mathematics Olympiad held both elementary / MI, SMP / MTs., SMA / SMK / MA even the level of Students. But sometimes those who can enjoy the Olympics are only certain schools. This is due to the lack of socialization conducted by the government regarding such activities as well as the factor of the school itself which still has a sense of inferior to compete with other schools. The purpose of this training activity is to improve the ability of students to solve Mathematics Olympic questions. The implementation of this activity was carried out at SMAN 2 Tanjung Balai, with the method of providing training and training strategies prepared by the writing team. the results of the training, that students are very enthusiastic in discussing Mathematical Olympiad problems with the tricks provided and they can easily answer the questions given without the constraints which means are expected to produce new seeds from the winners of the Mathematics Olympiad.
\end{abstract}

Keywords: Training, Problem Prediction, Mathematics Olympiad.

\begin{abstract}
Abstrak: Banyak cara yang ditempuh oleh pemerintah untuk mewujudkan sumber daya manusia Indonesia dengan kemampuan intelektual yang dapat bersaing dengan daerah bahkan dengan Negara lain, salah satunya dengan diadakan Olimpiade Matematika baik tingkat SD/MI, SMP/MTs., SMA/SMK/MA bahkan tingkat Mahasiswa. Namun terkadang yang bisa menikmati kegiatan olimpiade tersebut hanyalah sekolah-sekolah tertentu saja. Hal tersebut disebabkan masih kurangmya sosialisasi yang dilakukan pemerintah mengenai kegiatan tersebut serta faktor dari sekolah itu sendiri yang masih memiliki rasa minder untuk bersaing dengan sekolahsekolah lain. Tujuan dalam kegiatan pelatihan ini adalah untuk meningkatkan kemampuan peserta didik dalam menyelesaikan soal-soal Olimpiade Matematika. Penyelenggaraan kegiatan ini dilaksanakan di SMAN 2 Tanjung Balai, dengan metode memberikan pelatihan dan strategi pelatihan yang sudah disiapkan oleh tim penulis. hasil pelatihan tersebut, bahwa siswa sangat antusias dalam membahas soal-soal Olimpiade Matematika dengan trik yang diberikan dan mereka pun dapat dengan mudah menjawab soal-soal yang diberikan tanpa kendala yang berarti diharapkan mampu menghasilkan bibit-bibit baru dari pemenang Olimpiade Matematika.
\end{abstract}

Kata Kunci : Pelatihan, Prediksi Soal, Olimpiade Matematika. 
Available online at https://jurnal.stmikroyal.ac.id/index.php/jurdimas

\section{PENDAHULUAN}

Program pengabdian kepada masyarakat yang berada dibawah naungan Lembaga Penelitian dan Pengabdian Masyarakat (LPPM) dan juga merupakan salah satu Tri Dharma dan menjadi tanggung jawab setiap dosen. Pengabdian kepada masyarakat adalah satu kewajiban dosen untuk negeri sekaligus menjadi aksi dari keterlibatan perguruan tinggi dalam pembangunan dan menghilangkan isolasi dunia akademik terhadap persoalana masyarakat.

Selain itu masyarakat juga akan mendapatkan bekal untuk menyelesaikan permasalahan dan menjawab tantangan dalam kehidupannya masyakat juga nantinya akan memberikan pembelajaran bagi perguruan tinggi tentang realita kehidupan. Masyarakat disini cakupannya sangat luas bisa mencakup peserta didik, guru, atau masyarakat RT/RW. Dalam mencapai kesuksesan tri dharma akan dialaksanakan pengabdian kepada masyarakat peserta didik denga tema kegiatan dalam bentuk "Pelatihan Persiapan Kegiatan Olimpiade Matematika Sebagai Tambahan Ekstrakurikuler" pelatihan tersebut meliputi kegiatan tahapan pertama memberikan arahan dan memaparkan beberapa pentingnya matematika untuk bisa di pahami, dan memberi paparan terkait beberapa trik jitu dan pendekatan menggunakan inquiry.

Memandang Banyak cara yang ditempuh oleh pemerintah untuk mewujudkan sumber daya manusia Indonesia dengan kemampuan intelektual yang dapat bersaing dengan daerah bahkan dengan Negara lain, salah satunya dengan diadakan lomba-lomba berupa Drama, Debat Bahasa Inggris dan Olimpiade Matematika baik tingkat
SD/MI, SMP/MTs., SMA/SMK/MA bahkan tingkat Mahasiswa. Namun terkadang yang bias menikmati kegiatan olimpiade tersebut hanyalah sekolahsekolah tertentu saja. Hal tersebut disebabkan masih kurangmya sosialisasi yang dilakukan pemerintah mengenai kegiatan tersebut serta faktor dari sekolah itu sendiri yang masih memiliki rasa minder untuk bersaing dengan sekolah-sekolah lain terutama sekolahsekolah yang berada di daerah atau pelosok.

Kaitannya dengan itu maka diperlukan peranan dari semua pihak untuk meningkatkan Sumber Daya Manusia. Berangkat dari itulah Dosen FKIP dari Universitas Asahan akan mengadakan pelatihan persiapan lombalomba Olimpiade Matematika disekolah SMAN 2 Tanjung Balai guna untuk menumbuhkan generasi-generasi muda yang handal dalam Matematika.

Dari pengalaman tim penulis, di SMAN 2 Tanjung Balai peserta didiknya masih mengalami kesulitan dalam mempersiapkan siswa-siswi dalam persiapan kegiatan lomba Olimpiade Matematikadi SMAN 2 Tanjung Balai. Hal ini juga berdasarkan pengamatan salah satu tim penulis yang juga bertugas sebagai staf pengajar di sana, sehingga tim penulis tertarik untuk melakukan pelatihan persiapan kegiatan lomba Olimpiade Matematika untuk di SMAN 2 Tanjung Balai tahun pelajaran 2017/2018.

\section{METODE}

Penyelenggaraan kegiatan ini akan dilaksanakan pada hari kamis, pada tanggal 08 maret 2018 - 10 Maret 2018 mulai pukul 08.00-14.30 WIB. Adapun tempat penyelenggaraan kegiatan ini di 
Available online at https://jurnal.stmikroyal.ac.id/index.php/jurdimas

SMAN 2 Tanjung Balai. Metode pelaksanaannya yaitu dengan memberikan pelatihan dan strategi pelatihan yang sudah disiapkan oleh tim penulis yaitu menggunakan pendekatan Inquiry yang dikemas dengan menggunakan trik cepat dalam menyelesaikan soal.

Adapun materi yang akan ditawarkan untuk memecahkan permasalahan adalah sebagai berikut : Materi Aljabar, Teori Bilngan, Geometri OSK, dan materi Kombinatori denga tahapan pelaksaannya sebabgai berikut:

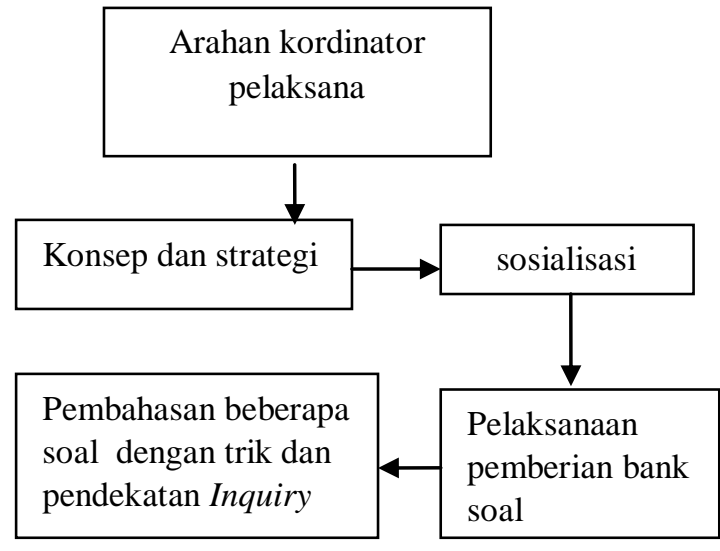

Gambar 1. Diagram Alur Metode pelaksanaan kegiatan

Dari metode tersebut selanjutkan akan dilihat bagaimana respon siswa terkait pelatihan yang dilaksanaakan dengan angket dan dilihat dari hasil jawaban setiap siswa dari bank soal yang diberikan.

\section{PEMBAHASAN}

Hasil dari pelaksaannya pelatihan berdasarkan wawancara, pengamatan langsung selama kegiatan berlangsung dengan tahapan dan persiapan yang telah dilaksanakan dari jumlah siswa sebanyak 50 siswa rata-rata memberi respon yang positif dan memberi hasil sebagai berikut:

a. Meningkatnya pengetahuan dan pemahaman siswa tentang materi yang disajikan

b. Meningkatkan keangkasan dan cepat tepat dalam membahas persoalan yang diberikan

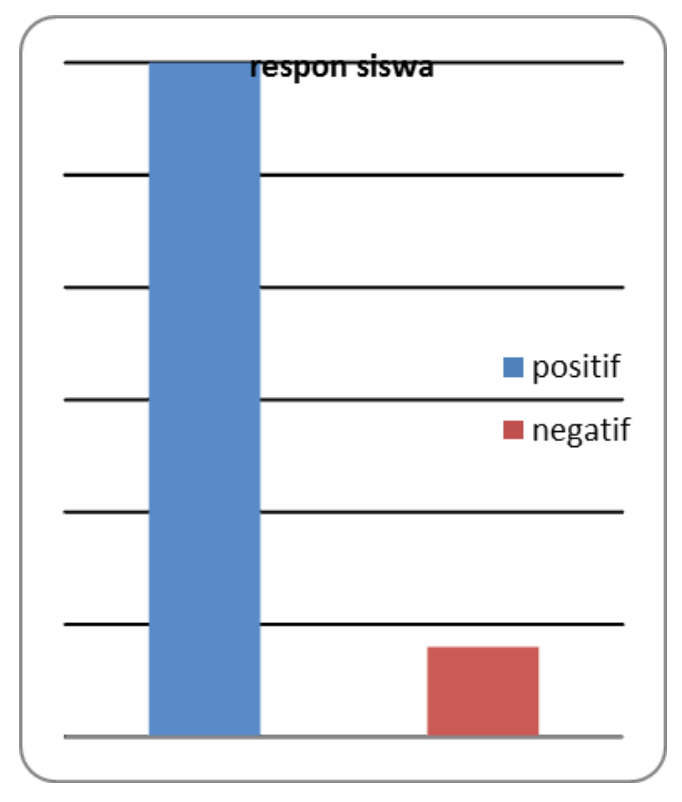

Gambar 2. Jumlah siswa dengan kategori nilai tinggi dan rendah

Pada tahap terakhir tim pelaksana memberi angket kepada responden siswa sekaligus penilaian dalam bentuk pengamatan untuk melihat respon siswa terhadap pelatihan yang di laksanakan, dan hasilnya siswa memberi respon positif dan sangat antusias selama dalam melaksanakan kegiatan. Hal ini sangat sesuai dengan pendekatan yang dilaksanakan yaitu pendekatan inquiry dimana siswa diharapkan mampu menemukan sendiri solusi dari permasalahan, dan dengan kombinasi trik jitu yang diberikan tim pelakasana yang semakin membuat siswa penasaran dan ingin terus mencoba mencari solusi setiap prmasalahan yang diberikan, dan sesekali tim pelaksana memberi bantuan/ 
Available online at https://jurnal.stmikroyal.ac.id/index.php/jurdimas

scafollding untuk siswa yang kurang paham.

\section{SIMPULAN}

Berdasarkan pelaksanaan diketahui bahwa siswa sangat antusias dalam membahas soal-soal Olimpiade Matematika dengan trik yang diberikan dan mereka pun dapat dengan mudah menjawab soal-soal yang diberikan tanpa kendala yang berarti sehingga dapat:
a. Meningkatnya pengetahuan dan pemahaman siswa tentang materi yang disajikan
b. Meningkatkan ketangkasan dan cepat tepat dalam membahas persoalan yang diberikan

\section{DAFTAR PUSTAKA}

Alberta. 2004. Focus on Inquiry : A Teacher's Guide to Implementing Inquiry-Based Learning. Learning and Teaching Resources Branch, Canada.

Hoseana, Jonathan. 2016. Top Sukses Olimpiade Matematika SMA/MA. Grasindo: Jakarta.

Tim penulis. 2013. Buku Guru Kurikulum 2013 cetakan ke1.Jakarta : Kementerian dan Kebudayaan.

Trianto. 2013. Mendesain Model Pembelajaran Inovatif Progresif, Konsep, Landasandan Implementasinya pada Kurikulum Tingkat Satuan Pendidikan (KTSP). Jakarta: Kencana Prenada Media Group 